\title{
TĚŽKÝ ŽIVOT UKRAJINSKÉHO STUDENTA PRAŽSKÉ LÉKAŘSKÉ FAKULTY (Úvaha o dvou anonymních př́spěvcích Peroutkovy Př́tomnosti z roku 1930)
}

\author{
BOHDAN ZILYNSKYJ
}

\begin{abstract}
HARD LIFE OF A UKRAINIAN STUDENT AT THE PRAGUE FACULTY OF MEDICINE (Thoughts Upon Two Anonymous Contributions in Peroutka's Prítomnost, 1930)
\end{abstract}

The author reveals the identity of authors of two articles, which were published anonymously in 1930 in the Pritomnost weekly under a joint title 'Hard Life'. The author managed to find out that one text was written by Ivan Lukaščuk, then student at the Faculty of Medicine of the Charles University in Prague, later physician, a man who belonged to a generation of military émigrés from Western Ukraine. This contribution includes his biography until 1936, when all traces of him in all available sources disappear. The second text was written by his partner, Růžena Linková.

Keywords: Ivan Lukaščuk - medical studies - Charles University - Přitomnost (Ferdinand Peroutka) - Ukrainian emigration -1930 s

DOI: $10.14712 / 23365730.2018 .26$

I.

Týdeník Přitomnost, redigovaný Ferdinandem Peroutkou, jedním z nejpřednějších českých novinářů, sledoval široké spektrum otázek tehdejšího života. ${ }^{1} \mathrm{~V}$ Přitomnosti byla už od prvního ročníku, tedy od roku 1924, zařazována i rubrika „Doba a lidé“. Právě v ní byly v létě roku 1930 otištěny bezprostředně po sobě dva př́íspěvky neznámých pisatelů, opatřené společným názvem Těžkýžzivot. ${ }^{2}$ Osoba, která oba materiály upravila do tisku, není u žádného $\mathrm{z}$ nich uvedena. $\mathrm{V}$ obsahu ročníku je však označen za autora těchto př́spěvků kdosi, skrytý pod pseudonymem Zvědavec V. K. ${ }^{3} \mathrm{~V}$ redakčním úvodu prvního z Těžkých životů se o něm píše jen toto: „Sociolog, pracujicí na vylićení života vydělávajicích studentů, poslal nám dvě studentské zpovédi.“

1 Je překvapivé, že dosud nebyla vytvořena monografie tohoto významného časopisu. Srov. aspoň heslo "Př́itomnost“" in: Lexikon české literatury, 3/II, Praha 2000, s. 1151-1155 (autor hesla: Vladimír Forst).

2 Těžký život, I, Př́itomnost 7, 1930, s. 476-478 (̌̌. 30 z 30. 7.), II, ib., s. $492-494$ (č. 31 z 6. 8.).

3 Autor užívající tohoto pseudonymu publikoval v tomtéž ročníku ještě článek $K$ psychologii jihočeské vesnice, tamtéž, s. 525-527 (č. 33 z 20. 8.), zařazený do téže rubriky. K jeho identifikaci tento článek nijak nepřispěje. 
Nejde o jediný materiál Př́tomnosti z uvedeného roku, který projevoval zájem o životní podmínky nejmladší generace. Mezi polovinou října a listopadu 1930 otiskl Ferdinand Peroutka tři materiály diskusní či polemické povahy, které se dané tematiky týkaly. ${ }^{4}$ Bylo snad projevem stejného zájmu, že o čtvrt roku dřive zařadil zpovědi obou studentů medicíny.

Máme tedy k dispozici „dvojmateriál“", charakterizující život dvou chudších studentů pražské medicíny. ${ }^{5}$

Nejprve dostaly prostor vzpomínky české studentky ${ }^{6}$ která se však zřejmě brzy po začátku studií dostala do finanční tísně a nemohla v nich celých pět let, od podzimu roku 1925 do jara 1930, pokračovat. Po celé toto období pracovala, aniž by se přitom mohla na fakultu vrátit. Identifikovat mladou autorku jen na základě toho, co o sobě napsala, není možné. Jisté je pouze to, že byla dcerou nepř́iliš úspěšného hostinského z blíže neznámé části českého venkova. Jen prvním písmenem (K., H., D. B.) uvádí jména lokalit v oblasti svého venkovského bydliště. Zaměřuje se téměř jen na popis, respektive na osobní a sociální aspekty plejády zaměstnání, která postupně vykonávala v blízkosti rodiště i v Praze.

Dívka místo studia pracovala $\mathrm{v}$ hostinci provozovaném její sestrou, pak jako pomocnice $\mathrm{v}$ domácnosti, následně $\mathrm{v}$ jiném hostinci, znovu $\mathrm{v}$ domácnosti a ještě jednou u sestry. Teprve na jaře 1929 získala zaměstnání v Praze - nejprve v tiskárně a poté jako uklízečka v kanceláŕích nově zaváděné firmy. $V$ době sepisování svého textu stále doufala, že lékařská studia dokončí, a to i s pomocí nového známého a partnera, autora druhých memoárů. O svém předchozím gymnaziálním ani univerzitním studiu se nezmiňuje. Nejde tedy vlastně o př́́spěvek $\mathrm{k}$ dějinám studia medicíny.

Druhý text o těžkém životě, ${ }^{7}$ který nás bude v tomto článku zajímat nejvíce, charakterizoval redakční úvod jako text „Ukrajince-emigranta“ a dodává, že ,jeho náčrtek vystihuje dobře i psychologii emigrantů u nás" ${ }^{8}$ Tento text je přitom obsahově blízký rozsáhlejší reportáži o několika jednotlivcích z prostředí ruské emigrace, která začala vycházet o číslo dřive. Její první část bezprostředně předcházela textu již zmíněné studentky medicíny. ${ }^{9} \mathrm{Zda}$ se jednalo o náhodu, nebo programový záměr redaktora, není zřejmé.

Ukrajincův text se od vzpomínek neznámé studentky výrazně liší. Autor o sobě prozradil více. Jeho nepochybně dramatičtější vyprávění popisuje téměř jedenáct let života, počínaje rokem 1919. Tehdy se jako př́islušník ukrajinské (respektive západoukrajinské) armády zúčastnil ukrajinsko-polské války o východní Halič, která začala v listopadu 1918 a skončila porážkou Ukrajinců v červenci 1919. Už o dva měsíce dř́ve, 20. května 1919,

4 Př́slušné texty srov. in: Ferdinand Peroutka, Polemiky (Polemické stati z let 1924-1948), Praha 1995, s. 53-63).

5 O meziválečných studentech Lékařské fakulty Univerzity Karlovy víme jen málo, srov. Ludmila HLAvÁčKovÁ Petr Svoвodń̛, Dějiny pražských lékařských fakult (1348-190), Praha 1993, s. 107-110. Bylo by potřeba najít pro srovnání některé jiné memoáry týkající se tématu. Jiří SyLLABA, Vzpomínky a úvahy lékaře, Praha 1992, s. 41-48, vzpomíná na své studium konané v letech 1920-1926, jako syn univerzitního profesora a lékaře byl však zjevně v úplně odlišné situaci.

6 Príitomnost 7, 1930, s. 476-478 (̌̌. 30 z 30.7.).

7 Tamtéž, s. $492-494$ (č. 31 z 6. 8.).

8 Tamtéž, s. 492. Jen v menší míře k nim patřila ukrajinská tematika, které se Př́itomnost nevěnovala nijak pravidelně ani do hloubky. V prvních třech ročnících (1924-1926) zde sice publikoval známý ukrajinský exilový novinář polského původu Hyppolit Boczkowski, do listu však psal většinou o neukrajinských tématech.

9 Dr. Franko, Na ruinách ruské emigrace, tamtéž, s. 474-476, 490-492, 571-573, 605-606, 619-623. Části otišstěné souběžně s dvojicí česko-ukrajinského materiálu nesou podtitulky Kolja pěchotinec a Kdo je ,Strelok a z koho žije? (tamtéž, s. 474-476), cyklus pak dále pokračoval ještě čtyřmi částmi. Ani o osobě a národnosti dr. Franka nelze ř́íci nic určitého. 
přešel budoucí student medicíny se svou jednotkou přes Karpaty do části Uherské (později Podkarpatské) Rusi, která už byla pod kontrolou československé armády. Byl pak dopraven do internačního tábora $v$ Německém Jablonném, zde absolvoval předmaturitní kurz a 20. května 1920 - rok po př́íchodu do ČSR - složil zkoušku dospělosti.

Poté byl odeslán do Prahy s vojenským pracovním oddílem a zapsal se na Právnickou fakultu Univerzity Karlovy. Po absolvování tř́ semestrů se musel z Prahy vrátit do Josefova, kam byli posláni ukrajinští vojáci z Jablonného i Liberce. Teprve roku 1924 přišel autor zpět do české metropole a zahájil souběžné studium na Lékařské fakultě Univerzity Karlovy a na Filozofické fakultě Ukrajinské svobodné univerzity.

Detailnější údaje o průběhu studia autor uvádí jen v př́ípadě univerzity české, není jich však mnoho. Soustřed’uje se totiž hlavně na sociální momenty, respektive na způsob, jakým získával nezbytné finanční prostředky od prázdnin roku 1924. Zmiňuje svou tehdejš́i účast na stavbách kolonie Na Cibulce v Košiŕích, při stavbě holešovického, či spíše libeňského mostu, a kdesi na Újezdě. Zde ho postihl lehčí pracovní úraz, kvůli kterému musil toto zaměstnání opustit. Sám o tom ř́ká: „Největší bolest mně pak způsobilo, že mistr mi k tomu ještě hodně sprostě vynadal a $k$ dovršení všeho ještě mi řekl, že ví, že studenti se nehodí k ničemu, $k$ žádné práci, že každý chce jenom dva, tři dni pracovati a pak několik měsiců maroditi.“

Poté mu nezbylo než brát zavděk hůře placenými pracemi, o nichž žádné podrobnosti neuvádí, neříká ale nic podstatného ani o svých studiích. Do textu vstupuje jako větší exkurz až zpráva o dvou změnách $\mathrm{v}$ autorově osobním životě. Nejprve se, zřejmě na podzim 1924, dověděl o smrti obou rodičů, kteří zůstali ve východní Haliči. Nedlouho poté, o silvestru, se seznámil s kuchařkou venkovského původu Miluškou - její příjmení neuvádí. Po tříleté známosti, v době, kdy ještě neměl složeno druhé rigorózum, uzavřel s ní po jejím narůstajícím naléhání církevní sňatek. „Den před svatbou vypůjčil jsem si černé parádní šaty a všecko potřebné, takže jsem mèl na sobě pouze svou vlastní košili, kromě toho dostal jsem dvě láhve červeného Malaga-vína. Ráno před 7. hodinou dne 6. 3.1928 vypil jsem půllitru vína a šel jsem se ženiti - nežjsem došel, byl jsem v kostele napolo opilý, takže jsem si ani správnè neuvédomil, co př́sahám."

Novomanžel dostal od nastávajícího tchána konkrétní sliby ohledně svého finančního zajištění. Po svatbě se sice důkladně najedl (,to bylo celé mé věno a všecko z těch slibư"), ukázalo se nicméně, že jeho vstup do nového života nebyl zrovna št’astným krokem. Potvrdily to už prázdniny téhož roku, na které student odjižděl s druhým rigorózem v kapse, „vyjma farmakologii a dětské nemoci, z kterýchž predmětů jsem propadl, takže po prázdninách mél jsem platiti 180 Kč reparační taxy". Švagr sice poslal autorovi z Polska do ČSR 900 Kč, ty však dal novomanžel neprožretelně své ženě a už se s nimi neshledal. Naprosté omezování vlastních finančních potřeb ho uráželo, zvláště když se stal svědkem tchánovy marnotratnosti. Následovalo rozhodnutí pobyt v manželčině rodině i krátce trvající rodinný svazek ukončit.

„Doktor bez pjaty chvylyn“"10 se bez peněz vrátil do Prahy a probíjel se s nesnázemi dalšími měsíci, zprvu musel např́íklad nocovat „, houští nahoře v Kinského zahradě“. Manželce neodpustil, ani když se za ním koncem října vrátila s prosíkem: byl už rozhodnut se s ní natrvalo rozejít (,jen rozvod může býti východiskem"). Nedostatek financí ho však

10 Takováto formulace („,doktor bez pěti minut“) se užívala v tehdejší ukrajinštině pro už skoro hotového doktora. 
pronásledoval dál (nepomohlo ani zastavení snubního prstenu) a bohatší kolegové mu už nechtěli peníze půjčovat (,ostatně méli pravdu - vždyt’ jsem skoro už ze zásady nevracel, protože jsem neměl nic").

Nejhưře bylo po únoru 1929, kdy student dostal výpověd’ z bytu. Popis jeho života v následujících týdnech působí tristně. „Chodival jsem každodenně k Beránkovi na Vinohradech, koupil jsem za korunu 10 dkg reklamního salámu a 1/4 kg chleba za 80 halérù a na trhu za 20 hal. česnek, a to byla moje snídaně, oběd a večeře. Vyspával jsem, kde se dalo, na novostavbách nedostavených ve sklepu, ale musel jsem ráno časně vstávati, jinak by bylo zle a ztratil bych svioj zdarma sice, nepohodlný, ale prece tak drahý byt. Chodil jsem v jednom límci a jednom prádle do 12. dubna, tašku s knihami měl jsem za podušku (míněn je zřjejmě polštář - pozn. autora) a prikrýval jsem se jedině pláštěm, který mi podaroval jeden kolega. Na přednášky jsem nechodil, protože jsem se styděl před kolegy, a když jsem byl už na vrcholu nouze, takjsem šel do kterékoliv restaurace, ohlašoval jsem se jako zpěvák národnich písni a nejednou mi za to poskytli také jídlo a pití, a kromě toho jsem někdy vybral přes $40 \mathrm{Kč}$, takže mi to pak stačilo na celý týden. Mezitím jsem pilně studoval.“

To byly asi nejsložitější okamžiky autorových studentských let, které s menším časovým odstupem glosuje následovně: „Tragika života - a prece tak lpíme na něm i v nejhorši bídě a tak neradi se loučíme s ním - vždyt’ je skutečně krásný, jen se musíme naučiti správně se na něj divati. Pozoruji, že jaksi ještě při psani těchto řádek proživám tyto momenty a myslím, že zkušený grafolog by okamžitě poznal vzrušení při analyse písma." "11

Blížil se však obrat k lepšímu. Jeho popis autor avizuje citátem německého rčení „Wo die Not am grössten, ist die Hilfe am nächsten“ a pokračuje slovy: „Dne 12. dubna 1929 vybral jsem se po 11. hodině dopoledni do pathologického ústavu prof. Hlavy ne v tom úmyslu, abych poslouchal přednášku, ale abych si u mladšich mých kolegů vypůjčil několik korun. Sedl jsem si do nejhořejši lavice, abych měl přehled po přednáškovém sálu (pathologii měl jsem už pres rok hotovou). Za přednášky prof. Kimly ${ }^{12}$ takjsem byl zaujat, že jsem najednou zapomněl na hlad a sestoupil jsem až do první lavičky [!], abych lépe viděl na preparáty rüzných chorobně změněných orgánů lidských - vytrval jsem tam hodně dlouho, pak jsem

$11 \mathrm{O}$ autorově životním názoru svědčí partie, kterou ve svých mikromemoárech umístil už dříve: „ačkoliv jsem se jen jakž takž udržoval na úrovni životní, přece jsem neklesl na duchu a byl jsem vždy v naději, že za nějaký čas se poměry zlepší a člověk si po tak dlouhé době oddechne a řekne si s vědomím vnitřního zadostiučinění: „Já jsem bojoval v životě čestně a jsem si vědom svého silnějšího ,jáa“‘. Vím ze zkušenosti, že člověk dovede si vynahraditi jedním světlým okamžikem dlouhá léta utrpení, a že člověk, který ve svém životě netrpěl, je zpravidla připraven o mnoho požitků a pocitů radosti člověka mnoho vytrpěvšího. Zapsal jsem si do svého denního zápisníku dvě věty - jednu anglickou: ,The power of the mind over the body“ a druhou francouzskou: ,C'est la foi, qui guérrit ${ }^{*}$ - a nahoře nad tím: ,Omnia ad maiorem Dei gloriam‘. Jsou různé tradicionální předsudky, pozůstalosti [!] to z dávných dob našich předků, které, někdy na pohled pranepatrné, silně rozhodují v našem životě, a jsem přesvědčen, že nic se nedá na světě a priori negovati. Nejsem náboženským fanatikem, také v některých věcech mám hodně pochybností, ale věřím pevně, že musí býti ve vesmíru síla, která řídí osudy lidstva a všeho dění - a tím [!] jest Bủh. Hledáme vždy důkazy jsoucnosti Jeho, protože mnoho lidí potřebuje duševní rovnováhy, která podle mého úsudku je nejvyšším myslitelným podkladem životním. A čím se získá? Jedině svědomitým vykonáváním své práce a životního úkolu. Soudím, že nic není na světě bezúčelné, nic absolutně nepotřebného, a že vše jest v příčinné souvislosti s děním dávno zašlých dob a směřuje kam? K udržení rovnováhy vesmíru." Př́ítomnost 7, 1930, s. 492-493.

12 Rudolf Kimla (1866-1950) se stal v roce 1911 ř́aným profesorem patologické anatomie Univerzity Karlovy. K němu srov. Petr SvobodnÝ, Rudolf Kimla: profesor LF UK v Praze a člen PAU v Krakově: $k$ dějinám česko-polských vědeckých styků v medicíně, Historia Slavorum Occidentis 1 (8), 2015, s. 192-211. Reprodukci Kimlova portrétu viz Jan HaVRÁNEK - Zdeněk Pousta (edd.), Dějiny Univerzity Karlovy, IV, 1918-1990, Praha 1998, s. 107. 
šel zase na své misto nahoru. Vedle mne si usedla nějaká kolegyně, která se mne otázala na podrobnosti zkoušek.“

Tento jediný výraznější úryvek autorových vzpomínek, týkající se př́imo studia, byl ovšem napsán jen proto, že předznamenal počátek jeho druhé vážné známosti. Tentokrát se jednalo o osobu, jež ,prožívala osudy dosti podobné mým. [...] Dospěl jsem k přesvědčení, že právě jako já padla jako obět zlých lidí. Neštěstí lidi více sjednocuje, štěstí zase podporuje sobectví a závist - tak jsme dva neštastníci sešli se v životě. Slíbil jsem jí, že budeme společně dále pracovati, poněvadž ve dvou se lépe táhne."

Tak začala nová etapa $\mathrm{v}$ životě autora i jeho dívky. Autor si půjčil taxu pro třetí rigorózum a do konce června 1929 složil zkoušky z př́slušných čtyř předmětů. Poté se vydali na prázdninový pobyt u rodičů dívky. Sluší se v této souvislosti dát slovo i jejím vzpomínkám: „Tak jsem myslela, abych se trochu zotavila - odjela jsem tedy na prázdniny, vzavši s sebou jednoho kolegu, také takového chudáka." V novém místě pobytu mladý pan doktor, jak ho tam už nazývali, pracoval na poli i v domácnosti (,to byl náš odpočinek - nadřeli jsme

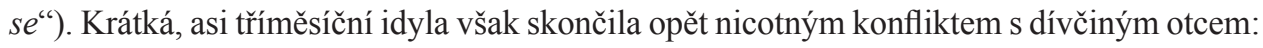
důvodem byl autorův př́liš̌ hlasitý zpěv v hospodě. Následoval opět odjezd, v tomto př́ípadě už obou mladých lidí, do Prahy, kde se probíjeli životem dál.

O této několikaměsíční etapě mluví autor opět jen stručně, některé údaje ale přidala ve svém vyprávění jeho dívka, která pracovala nově (od prosince 1929) jako uklízečka v kanceláři: „Pracuji tam 2-3 hodiny týdně, takže ostatní čas zbývá mi ke studiu. Hrubši práce jako leštěni parket, čištěni parket obstarává za mne zatím již Dr. med., můj kolega ve štěstí i neštěstí. Budu ráda, až i já skončím svá studia, ale přesto vždy vzpomenu si, jak jsem vkročila do života ,životem ".“

Text autorova vyprávění končí lakonickým sdělením: „Dne 30. června (1930 - pozn. autora) jsem měl promoci. "Bylo to tedy pět týdnů před otištěním jeho vzpomínky a pak zbývalo dotáhnout $\mathrm{k}$ úspěšnému završení studia jeho partnerky. $O$ tom, zda se to podařilo, se už z Př́tomnosti nedovídáme. Co se týče jiných věcí, něco napovídá závěr redakčního úvodu ke studentčiným pamětem: „Závěry z této četby necht'si udělá čtenár sám. Jak nám náš informátor oznamuje, bude to míti happy end: oba ti lidé patři k sobě, a co nejdřive se vezmou."

II.

Zde by text tohoto krátkého článku mohl či měl skončit, všichni však víme o užitečnosti „kanceláře pro uvádění románových př́běhů na pravou míru“. ${ }^{13}$ Zkoumaný text sice vysloveně románovou látku nenabízí, je však čas na vysvětlení, jehož existence byla ohlášena v úvodu tohoto článku.

Prvním problémem k řešení bylo to, který autor, v tomto př́ípadě ale spíše editor, se skryl pod pseudonymem K. V. Zvědavec a byl v Př́tomnosti představen jako sociolog. ${ }^{14}$ Termín mohl tehdy znamenat jak dostudovaného, $v$ oboru aktivního sociologa, tak studenta tohoto oboru. S ohledem na iniciály K. V. by bylo možno uvažovat o autorství novináře širokých

13 Zdeněk JiRotкA, Saturnin, Praha 1942, s. 240-249, tj. text 25. kapitoly knížky.

14 Josef VopraviL, Slovník pseudonymů v české a slovenské literatuře, Praha 1973, pseudonym K. V. Zvědavec neuvádí - najdeme zde jen pseudonym Zvědavý. 
zájmů, překladatele z ruštiny a oběti nacistického režimu Václava Koeniga (1897-1944). Koenig v Přitomnosti publikoval v letech 1926-1932 a není proto jasné, proč by užil pouze u tř́i konkrétních př́spěvků „Zvědaveckého“ pseudonymu, když jinak podepisoval své materiály plným jménem.

Důležitá, ale neméně složitá je otázka, kteří dva lidé napsali příspěvky otištěné v Př́itomnosti. Identitu ukrajinského absolventa pražské medicíny se odhalit podařilo. $\mathrm{V}$ tzv. doktorské matrice Univerzity Karlovy, vedené tehdy pro všechny fakulty společně, je velký počet zápisů z 30. června 1930. Mezi novými doktory všeobecného lékařství jsou uvedeni dva Ukrajinci - Vjačeslav Javorskyj (narozený 1895 v Kamenci Podolském v ruské části Ukrajiny) a Ivan Lukaščuk (narozený v roce 1897 v Zabolotově v rakouské Haliči).

O tom, kdo z nich byl autorem článku, mohly rozhodnout jen katalogy posluchačů Lékařské, případně Právnické fakulty Univerzity Karlovy. Kontrolou údajů uvedených v př́ispěvku lze snadno zjistit, že autorem textu o těžkém životě byl právě Lukaščuk. Jeho studium trvalo, jak lze ověřit $\mathrm{v}$ zápisových knihách lékařské fakulty, od zimního semestru 1922-1923 do zimního semestru 1927-1928, tedy pět a půl roku. Poslední zapsaný semestr se překrýval s dobou uzavření Lukaščukova neúspěšného sňatku.

Lukaščuk je zcela neznámou postavou v rámci ukrajinské emigrace v ČSR: základní evidenční dílo z roku 1943 tohoto emigranta nezmiňuje. ${ }^{15}$ Článek Přitomnosti a univerzitní materiály zachycují jeho život jen do roku 1930, o dalším období už tyto zdroje nic nevypovídají. Bylo třeba hledat jinde a nakonec jsem mohl využít poměrně zajímavého osobního spisu Lukaščuka z fondu Policejní ředitelství Praha v Národním archivu Praha. ${ }^{16}$

Spis obsahuje jednotliviny z let 1928-1936 a posouvá př́běh alespoň o šest let dopředu. Cenná je zejména Lukaščukova dvoustránková strojopisná autobiografie z počátku dubna 1935, opakující a rozhojňující některé údaje textu Přitomnosti. Dovídáme se zde například, že Lukaščuk se opravdu pokusil pracovat jako lékař, nejprve na vnitřním oddělení profesora Eiselta v Masarykových domovech v Praze-Krči (po část let 1930 a 1931). V roce 1932 pracoval už jen tř́ měsíce jako výpomocný lékař v sanatoriu doktora Šimsy v Jablonném nad Orlicí. Poté už zůstal téměř neustále bez zaměstnání. Zřejmě působil jen krátce v sanatoriu doktora Borůvky v Praze, Legerově ulici, odkud byl propuštěn pro opilství. V době, kdy zůstal bez zaměstnání, žil zjevně z peněz, které mu nadále posílal jeho švagr z Polska - šlo o zhruba 700-800 Kč měsíčně.

Hlavním tématem policejního spisu jsou však opakované projevy Lukaščukova alkoholismu. V době, kdy navázal svou druhou známost, měl už za sebou dvojí policejní zadržení kvůli tomuto prohřešku: první př́ípad takového typu byl zaznamenán v bř̌znu 1929. Později, v letech 1930-1935, se situace minimálně třináctkrát opakovala. Pro ilustraci uvádím barvitý popis události z 30. června 1933, kdy byl Lukaščuk zadržen pro opilství a výtržnost na Karlově náměstí: „Byl nalezen v jiźzdni dráze na Karlově náměstí ležeti a byl tak opilý, že nevěděl, co čini. Strážník Blesk jmenovaného zvedl a vyzval jej, aby ho následoval, týž však prohlásil: ,Já jsem vysokoškolák, já s Vámi nepuijdu a Vy jste na to ještě moc mladej!' Později si to však Lukaščuk přeci jen rozmyslel a vyzvání strážnika uposlechl. Týž byl ponechán

15 Symon NARIŽNYJ, Ukrajinska emigracija (Kulturna pracja ukrajinskoji emigraciji miž dvoma svitovymy vijna$m y)$, častyna 1, Praha 1943, neuvádí Lukaščuka v rejstř́́ku textové ani obrazové části.

16 Národní archiv (dále NA) Praha, fond Policejní ředitelství (dále f. PŘ) Praha, II - všeobecná spisovna, k. 8522, sign. L 1728/ 7, manipulační období 1931-1940. Za pomoc při hledání spisu i jiné dokumentace jsem velmi zavázán Davidu Hubenému z Národního archivu ČR. 
do vystř́zlivěni a úredního rozhodnutí v policejni separaci. Počínání Lukaščukovo mělo za následek větší sběh obecenstva."

Opakování takových situací vedla v následujícím roce k vyjádření Poradny pro duševní hygienu (protialkoholní oddělení) ve Vršovicích. Ta v př́ípisu z 27. ledna 1934 navrhla, aby byl Lukaščuk jako chronický alkoholik, který zneuživá dobročinnosti svých kolegů a veřejnosti, vypovězen jako nepohodlný cizinec z Československa. Brzy poté, 6. března 1934, byl Lukaščuk zadržen, protože už od roku 1930 neměl žádné povolení k pobytu v republice. Když doznal, že se od roku 1930 zdržuje v ČSR bez platného dokumentu, byl odsouzen ke čtyřem dnům vězení. Poté podal žádost o uznání polské státní příslušnosti - rozhodl se tedy vrátit po patnácti letech domů. Polský konzulát v Praze 12. března 1934 oznámil, že cestovní pas Lukaščuka bude vydán až po provedení nezbytné korespondence s polskými úřady.

Polsko však o Lukaščuka nestálo - vojvodský úřadu ve Stanislavově mu přípisem z 21. ledna 1935 odmítl potřebný doklad vydat. Lukaščukova situace se tím zásadně zkomplikovala a on se pokusil uskutečnit záchranný manévr pořízením vlastního bytu. Od 3. dubna 1935 byl nahlášen v Bořivojově ulici na Žižkově. ${ }^{17}$ O týden později požádal ministerstvo vnitra o povolení $\mathrm{k}$ pobytu $\mathrm{v}$ ČSR bez cestovního pasu a připojil už zmíněný životopis. Poskytuje několik cenných údajů o jeho životě během necelých pěti let od promoce. Československé úřady však nehodlaly vyhovět. Dne 18. 5. 1935 navrhlo pražské policejní ředitelství zemskému úruadu v Praze, aby byl Lukaščuk považován za obtížného cizince a jeho žádost byla odmítnuta. Poté měl být vyhoštěn a odeslán na československo-polskou hranici.

Dne 14. ř́ína 1935, osm dní po posledním zadržení pro opilství i nezaplacení nevelké úhrady v hostinci Na Perštýně, byl Lukaščuk vyslechnut v prezidiu policejního ředitelství a v týž den navždy vyhoštěn z Československa. Realizaci rozhodnutí mělo zajistit hnanecké komisařství hlavního města Prahy. Dne 18. ř́ijna 1935 byl Lukaščuk opravdu donucen $\mathrm{k}$ přechodu hranice do Polska a vydal se pěšky, s kufrem na zádech, do rodné obce Zabolotova. Zde se úředně hlásil 8 . listopadu, byl ale vykázán zpět do ČSR, kam se musel vrátit. Hranici překročil 11. března 1936 přes karpatský hřeben a dostal se na území Podkarpatské Rusi.

O měsíc později následovalo druhé vykázání Lukaščuka z ČSR do Polska, ve Stanislavi ho však stihlo další zatčení a následovalo nové vypovězení do ČSR - hranici byl donucen překročit 27. dubna 1936. Ocitl se znovu v Podkarpatsku, v tehdy nejvýchodnějším československém městě Jasiňa, odkud požádal v týž den pražské ministerstvo vnitra o povolení k pobytu v ČSR. Poukázal zde na nenormálnost své situace a upozornil, že jeho př́pad je „plná analogie právního a materielního stavu Nikolaje Genyka, táboř́cího v kolybě [!] u Stavného na pomezí (původně psáno: pozemí; pozn. autora) hranic československo-pol$s k y ́ c h$ “. Také Genyka si Československo a Polsko posílaly ,na stř́dačku“ tam a zpět, a proto musel řešit situaci delším pobytem na hraniční čáře. ${ }^{18}$

Lukaščuk se dostal ještě jednou do Prahy, kde byl 2. července 1936 ve čtvrt na deset večer zadržen ve vysočanské noclehárně. Měl tehdy u sebe mj. Kalendár̆ československých lékařu a spis z Kanceláře prezidenta republiky. Den poté byl znovu vyslechnut a odsouzen

17 V předchozích necelých třinácti letech, od listopadu 1922, vystř́íal Lukaščuk v Praze dvacet dvě místa pobytu $\mathrm{v}$ deseti městských částech, nejčastěji na Malé Straně a Žižkově.

18 O tomto problému psal pod značkou K. Č. i Karel ČAPEK, Genyk, Lidové noviny 44, 1936, č. 195 (17. 4.), s. 5, a TÝž, Udělejme už jednou konec s tou ostudou!, tamtéž, č. 456 (11. 9.), s. 7. 
k dvaceti čtyřem hodinám vězení, pak měl být znovu dopraven na polské hranice. Poslední zpráva spisu uvádí, že byl zadržen 11. srpna 1936 v Košicích, kde pořídili a odeslali do Prahy otisky jeho prstů. Více se zatím nepodařilo zjistit.

„Kancelář pro uvádění románových př́iběhů na pravou míru“ musí v závěru tohoto článku s lítostí připojit ještě sdělení, že vztah dvou studentů medicíny, Ukrajince a Češky, prožívajících dvě varianty těžkého života, neskončil happy endem. Lukaščuk je v policejních pramenech uváděn do roku 1932 jako ženatý, vždy je však míněna manželka-kuchařka, se kterou prožil v roce 1928 pouhé tři měsíce. Materiály policejního ředitelství pomohly vysvětlit, že se jednalo o Emílii, rozenou Horákovou, narozenou v roce 1897 v Přepeřích u Turnova. ${ }^{19}$ Od svých sedmnácti let se protloukala životem v Praze jako př́ležitostně zaměstnávaná žena. Je zajímavé, že si i po rozvodu, který byl uskutečněn až 20. listopadu 1932, tedy po více než čtyřletém formálním manželství, ponechala příjmení Lukaščuková. Užívala je i v roce 1951, kdy žila v pražské Libni v neurčitém sociálním postavení. ${ }^{20}$ Až tehdy se s pomocí úřadů zbavila postavení osoby bez státní př́islušnosti. Dostala zpět československé občanství, které o dvacet tři let dřive sňatkem ztratila. O jejím dalším osudu nic nevím.

O druhé Lukaščukově družce, jejíž jméno nebylo v Přitomnosti uvedeno, se policejní spis Lukaščuka nezmiňuje. Na stopu mne naštěstí navedl drobný údaj jednoho z dokumentů tohoto spisu. Podle něj se Lukaščuk koncem záŕí 1929 zdržoval ve Střehomi v hostinci Dominika Linky. Zmíněná vesnička se nachází na Mladoboleslavsku a dnes je součástí Dolního Bousova. ${ }^{21}$ Následovalo pátrání v katalozích lékařské fakulty pražské univerzity po studentce Linkové. Ukázalo se, že Lukaščukovou druhou partnerkou se stala Růžena Linková, narozená v roce 1897 ve Střehomi. Tato absolventka českého vyššího dívčího gymnázia na Královských Vinohradech studovala na lékařské fakultě od zimního semestru 1916/1917 do zimního semestru 1922/1923. Tehdy byla zapsána do desátého semestru a k ukončení studia jí už zbýval jen krůček. Až do roku 1930, kdy už jí bylo třiatřicet, se jí ale studium ukončit nepodařilo. Lze vyslovit dohad, že $\mathrm{k}$ rozchodu Lukaščuka s touto dívkou, která mu byla víc než rok tak blízkou, přispěl partnerův sklon $\mathrm{k}$ alkoholismu.

Stopa po samotném Ivanu Lukaščukovi se nám, jak už bylo uvedeno, ztrácí v roce 1936, těsně před jeho čtyřicítkou. Pokud by se opravdu mohl vrátit do východní Haliče, prožil by v nejbližších letech dvojí násilné začlenění tohoto regionu do Sovětského svazu a mezi tím tři roky německé okupace. Nevíme však, kde Lukaščuk v tu dobu opravdu byl, kde se mohl nacházet např́íklad $\mathrm{v}$ roce 1951 a jakou existenci tehdy vedl. Bylo by mu $\mathrm{v}$ té době pětapadesát a dá se předpokládat, že alkoholismus doprovázený vědomím bezperspektivnosti vlastní existence doprovázely tohoto muže s doktorským diplomem až do jeho konce.

Meziválečné Československo poskytlo Ukrajincům a jiným emigrantům z evropského východu značné vzdělávací možnosti a dotovalo možnost jejich vysokoškolského studia. Řada Ukrajinců studium úspěšně dokončila a v praxi se dokázala uplatnit. Stejná možnost se rýsovala před Ukrajincem z Haliče Ivanem Lukaščukem. Studium opravdu ukončil

19 NA Praha, f. P̌̌ Praha, II - všeobecná spisovna, k. 6808, sign. L 2625 / 5, manipulační období 1941-1945.

20 Mezi lety 1929 a 1944 vystř́ídala v Praze dvanáct bydlišt', která se téměř vždy nacházela v Libni.

21 Připomínám, že sestra autorky žila podle jejího svědectví v místě, které ona sama označila v Přítomnosti písmeny D. B., tedy v Dolním Bousově. Je pozoruhodné, že návštěvě ve Střehomi předcházelo v polovině června 1929 odhlášení Lukaščuka z Prahy do Přepeř, tedy rodiště jeho manželky Emilie, s níž tehdy už celý rok nežil. Obě femmes fatales Lukaščukova života pocházely tedy ze stejné části Čech - ze středního Pojizer̂́i. 
a doktorát všeobecného lékařství získal, v praxi se však nedokázal na české půdě ani jinde uplatnit, mj. pro př́lišný sklon k požívání alkoholu. Jeho „hvězdná hodina“ přišla v létě roku 1930, kdy se představil, byt' anonymně, na stránkách Př́tomnosti. V tomto textu se projevil jako člověk nepochybně schopný a vybavený určitými ideály. Stačilo dalších šest let, aby se na české půdě doslova i symbolicky ztratil. V Peroutkově listu vystupoval v pozitivním kontrastu s bezprizorními ruskými emigranty, kteří získávali nezbytné finanční zdroje ,žebrotou vyšší úrovně“ u lépe postavených př́iznivců. Nakonec sám dopadl v jistém směru podobně. Zařadil se nakonec mezi početné meziválečné emigranty, kteří svůj těžký život prostě nezvládli. Vzpomněl si tehdy, nebo na úplném konci, na úvahy o vlastním životě i jeho určení a smyslu, které mu otiskli v Přitomnosti?

\title{
BOHDAN ZILYNSKYJ
}

\section{Das schwere Leben eines ukrainischen Studenten der Prager medizinischen Fakultät (Betrachtungen zu zwei anonymen Beiträgen in der Peroutka'schen Zeitschrift Prítomnost aus dem Jahre 1930)}

\author{
ZUSAMMENFASSUNG
}

Verfasser beschäftigt sich mit der Feststellung der Autorenschaft zweier publizistischer Beiträge, die 1930 in der bekannten, von Ferdinand Peroutka redigierten Wochenschrift Př́tomnost unter dem gemeinsamen Titel Těžký život („Ein schweres Leben“) anonym erschienen. Diese Beiträge behandeln die nicht einfachen Lebensbedingungen zweier Studierender der Medizin, die sich während der Abfassung dieser Beiträge zeitweilig näher kamen. Durch die Arbeit mit verschiedenen Quellentypen gelang die Feststellung, dass den ersten Text der spätere Doktor der Medizin Ivan Lukaščuk, Angehöriger der westukrainischen Militäremigration in der Tschechoslowakei, verfasst hatte und den zweiten seine Partnerin Růžena Linková, Tochter eines Gastwirtes aus Střehom. Der Text behandelt zumeist die voraufgegangenen Lebensschicksale von Lukaščuk, aber auch die Probleme, die er hatte, um eine seiner Bildung entsprechende Anstellung in der darauffolgenden Zeit zu finden, und zwar bis 1936, als sich seine Spur in den zugänglichen Quellen verlor. Der Beitrag weist auf die Probleme hin, die sowohl Lukaščuk als auch andere Emigranten trotz all ihrer Bemühungen und trotz der Hilfe, die ihnen seitens des tschechoslowakischen Staates zuteilwurde, zu Menschen machten, die als überflüssig oder für den Staat direkt als lästig empfunden wurden.

\author{
Bohdan Zilynskyj \\ Institut mezinárodních studií \\ FSV UK, Praha \\ z.bohdan@seznam.cz
}

